\title{
"Communicating Nation Branding through media and marketing strategies in the recent decade."
}

\author{
a second analysis review
}

Dr Hayat Badr *

ملخص الدراسة : تتناول هذة الدر اسة مجال صناعة العلامة التجارية للدول حيث جذب هذا

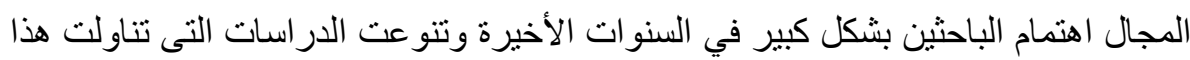

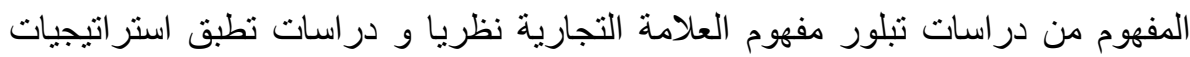

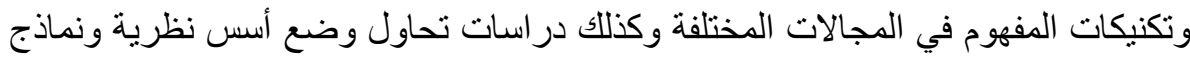
علمبة للمتغير ات المختلفة بعملية صناعة ولفيك الات الفيل العلامة التجارية للدول.

واعتمدت هذة الدراسة على محاول التركيز على الجانب التسويقي والإعلامي في دراسات

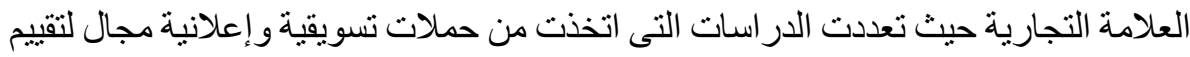

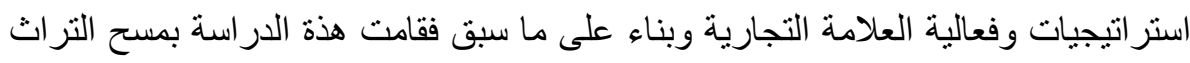

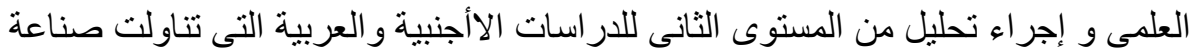

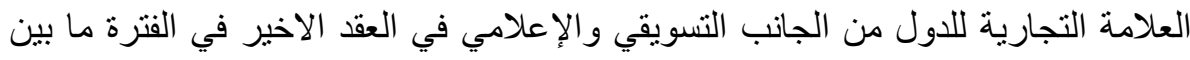

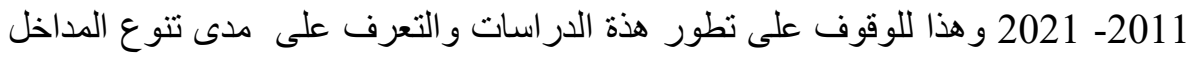

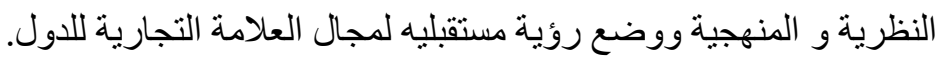

وتوصلت الدراسة إلى أن معظم الدراسات تطبق في الدول الأجنبية بنسبة أكبر من الدول

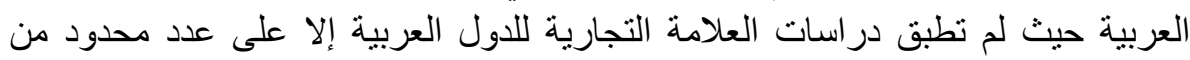

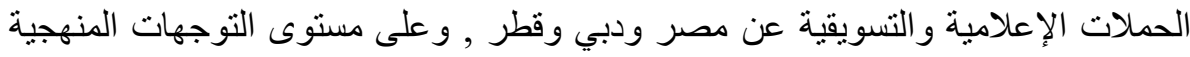

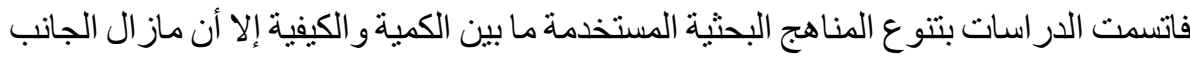

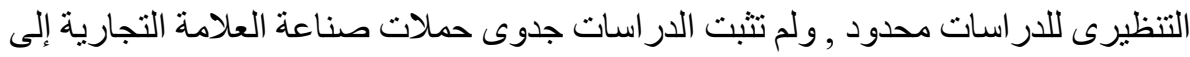

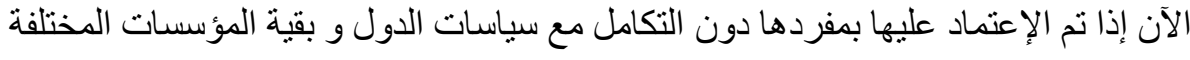

${ }^{*} \mathrm{PhD}$ holder and lecturer in public relations and advertising department Faculty of Mass Communication -Cairo university 


\begin{abstract}
:
This study deals with the field of nation branding, where this field has attracted the attention of researchers powerfully in recent years. A variety of studies dealt with this concept theoretically and applied strategies and tactics of the concept in different fields, as well as studies trying to establish theoretical foundations and scientific models for the other variables in making and activating the nation branding campaigns.

This study relied on an attempt to focus on the marketing and media aspect in nation branding studies, as many studies evaluated nation branding marketing and advertising campaigns strategies and effectiveness.
\end{abstract}

Based on the preceding, this study surveyed the literature review and conducted a second-level analysis of foreign and Arab studies that dealt with nation branding from marketing and media aspects in the last decade between 2011-2021 to determine the development of these studies and to identify the extent of the diversity of theoretical and methodological approaches and create a future vision for the field nation branding.

The study concluded that most of the studies are applied in foreign countries more than in the Arab countries, where the reflections of the nation branding of the Arab countries were only applied to a limited number of media and marketing campaigns on Egypt, Dubai and Qatar.

At the level of methodology, the studies were characterized by the diversity of research approaches used between quantitative and qualitative, but the theoretical aspect of the studies is still limited. The studies have not proven the feasibility of nation branding campaigns if they have relied on on without integration with the policies of countries and the rest of the various institutions. 


\section{Introduction}

Recently, nation branding studies have increased, especially after the significant interest of the international public relations and international marketing communications in general in building and improving the image of countries and promoting them to attract investments, tourists and improve political and diplomatic ties.

Nation branding is " a compendium of discourses and practices aimed at reconstituting nationhood through marketing and branding paradigms" ( Nadia Kaneva,2011:118 ). From this definition and others, the researcher found that many countries have passed through various political crises, wars and conflicts, as well as the events of the so-called Arab Spring for some Arab countries; this led to the emergence of the need for governments to communicate internationally, define themselves, their traditions and values, abolish their stereotyped image, and restore their status and stability through the mechanisms of soft power and public diplomacy

not only that, but also branding Countries for themselves and the consolidation of a positive image internally and externally in the minds of different peoples, which facilitates the processes of progress and development at all levels.

Based on that, the need to use marketing and public relations strategies and rely on the media to achieve nation branding has increased, whether by organizing international sports or cultural events, planning integrated marketing and advertising campaigns for countries' tourism promotion, or implementing integrated media campaigns to promote countries' policies, its Culture and achievements.

Which were followed by many media studies that were concerned with understanding the concept of nation branding scientifically and practically and putting forward theoretical foundations and models to facilitate its research and measurement and the development of public

The Scientific Journal of Public Relations and Advertising Research - Issue Twenty-Second - July / December 2021 
relations and marketing strategies for this field in addition to submitting future visions for research and studies that may contribute to the accumulation of the scientific literature of the nation branding studies field.

For the previously mentioned reasons, this study tried to present an attempt to conduct a review of the scientific literature in the last ten years for Arabic and English practical studies that focused on the field of nation branding from a direct media and marketing perspectives to identify the extent of development that occurred in the implementation of these studies, the nation brand concept and its various uses from countries, and on the other hand, a trial to know the role of integrated marketing communications with its different elements to promote countries and creating their brands and what this field needs in the future.

\section{First: Theoretical framework}

Anholt in1996 firstly introduced the nation branding concept as he examines how some countries can make their brands; researchers differ in defining nation branding as marketing scholars define nation branding as the combination of marketing tools in creating a unique brand for a country, others define nation branding as a destination marketing or in other terms as a place branding in which marketing and governmental efforts are used to promote specific area (Eli Avraham,2020).

Some scholars define nation branding from a political perspective and correlate the concept to public diplomacy umbrella and political public relations in elaborating how countries can use new public diplomacy initiatives through nation branding campaigns to face international terrorism threats and regain stability (Rasmus Kjærgaard Rasmussena, Henrik Merkelsen,2012), also the usage of nation branding concept in repairing the country image after political and cultural conflicts (Sara Currie, 2020 ). 
In addition to this, some studies like ( Somogy Varga,2013 )define the nation branding concept as a political marketing strategy that can help in sustainable development and the democratic process.

Also, recent studies investigated the nation branding concept from a cultural perspective, including various strategies like the spotlight on cultural values, traditions, sports, and the most recent strategy is focusing on people, especially women and promoting women empowerment as one of the nation branding techniques. ( ILHEM ALLAGUI, ABEER AL-NAJJAR 2018 )

Nation branding also was introduced containing six main elements in Anholt nation branding hexagon in which they are Exports which are simply the country labelled products, Governance. It can be measured through the trust in the government and its fair policies, Investments and Immigration, which is the extent of willingness to live and work in the country, Culture and heritage and the system of cultural values. People the famous persons of a particular country and finally, Tourism. ( Tamer Abdellatif,Dina Abboud, Sara Mohammed Mamdouh Abd El Azim,2019)

Nation branding is a vast concept that attracted the attention of many scholars for its importance; it can influence the country in many fields politically, culturally, economically.

Nation branding is recently becoming the tool for differentiating countries' products and broadening some countries' market share; it is also used to attract investments through tourism and migration.

Nation branding, as per this study, is the integrated marketing strategy that depends on different promotional tools, mainly advertising and public relations through traditional and social media, to promote the country's political, cultural, social, personal views to help to achieve a positive positioning locally and internationally in which it facilitates the economic and democratic process.

The Scientific Journal of Public Relations and Advertising Research - Issue Twenty-Second - July / December 2021 
Many studies concentrated on defining the nation branding concept from chosen perspective. Still, a few studies focused on combining media and marketing strategies in empirically implementing the idea of nation branding, which needs more investigation and theorizing.

And it was important for this study to take a new narrow lens to focus on it and go deeper in understanding the nation branding concept empirically through the media and marketing combination strategies in the recent decade as follow.

\section{Second: Methodological framework}

\section{1- Problem statement of the research}

The field of nation branding is one of the required fields with multiple dimensions, as it is studied in the political, cultural, economic and media aspects and depends on the role of the media in general and marketing in particular in the creation and promotion of the nation brand, whether locally or internationally, through the media coverage of various national events or the production of an integrated advertising and marketing campaign that promotes the image of the state with its different elements.

So It is crucial to shed light on Arab and foreign media studies that dealt with the concept of the nation brand from the marketing and media perspective, to know the various research trends on which they were based and the methodological and scientific developments to measure the concept and also to identify the future of these studies and its evaluation visions.

and based on this, the problem issue of this research is represented in "monitoring, analyzing and evaluating foreign and Arab studies in the period between 2011 to 2021, which dealt with the concept of a nation branding from a media and marketing perspective to know the theoretical frameworks that have been relied upon and 
developed, the different mechanisms of measuring the concept, to determine the efficiency of integrated marketing communications and media role in activating and creating the nation brand of different countries and research future trends in this field."

\section{2- Research objectives :}

- To identify the development pattern of the Arab and foreign studies that dealt with the nation branding concept from 20112021.

- To determine the theoretical framework and methodologies used in the reviewed studies.

- To determine the different themes and perspectives the reviewed studies dealt with in conceptualizing nation branding fields.

- To know the role of traditional and social media in activating nation branding concept.

- To know the role of integrated marketing communication strategies and campaigns in promoting the nation branding of different countries.

- To identify the main results of the reviewed studies.

- To present a future vision of research trends, issues and methodologies in this field.

\section{3- Research questions :}

a- What are the themes and perspectives on nation branding studies?

b- What are the theoretical frameworks used in the reviewed studies?

c- What are the methodologies that used in the reviewed studies?

d- What is the role of media and social media in promoting nation branding? 
e- What is the role of integrated marketing communication strategies and campaigns in creating and promoting nation branding?

f- Are there differences between Arabic and foreign studies in this field?

g- What are the main results of the reviewed studies?

h- How can this research present a future vision for future studies in this field?

\section{4- Research methodology :}

The current study belongs to the second level (meta) analysis studies in its qualitative style, which is a systematic method that depends on the analytical and methodological review that organizes studies and researches that have been published on a specific topic. ( Schulze, R., 2004)

And provide the researcher with an evaluation, analytical framework for the theoretical and methodological frameworks and the results reached by the studies.

This study reviews 55 studies ( full text ) published in scientific journals and masters and doctoral thesis. The studies varied between 53 studies in the English language and two studies in the Arabic language.

The sample distribution according to the publishing year is shown as follow :

\begin{tabular}{|c|c|}
\hline Year of publishing & No. of studies \\
\hline 2011 & 4 \\
\hline 2012 & 2 \\
\hline 2013 & 7 \\
\hline 2014 & 3 \\
\hline 2015 & 5 \\
\hline 2016 & 5 \\
\hline 2017 & 5 \\
\hline 2018 & 10 \\
\hline 2019 & 4 \\
\hline 2020 & 5 \\
\hline 2021 & 5 \\
\hline Total & 55 \\
\hline
\end{tabular}


Sample distribution according to the type of studies :

\begin{tabular}{|c|c|}
\hline Type of study & No. of studies \\
\hline Dissertations & 3 \\
\hline $\begin{array}{c}\text { Articles published in refereed } \\
\text { journals }\end{array}$ & 52 \\
\hline Total & 55 \\
\hline
\end{tabular}

-The sample of the current study was intentional and was chosen according to the following criteria :

-Studies dealt with the nation branding concept directly and mentioned it in the study title or its full text.

-Studies focus on the media and marketing perspective of the nation branding concept only.

Studies published between 2011 and 2021 as after 2011 the use of social media increased and some huge political events happened mainly in the Arabic countries like what was called Arab spring in which the demand of regaining countries image and stability improved. The dependence on the nation branding field increased.

-Studies that tailor the roles of marketing, public relations, advertising, image creation, reputation management and event organization in creating and promoting nation branding of various countries.

\section{Third: The themes and perspectives of the reviewed nation branding studies}

The reviewed studies tackled diverse perspectives and themes, beginning from conceptualizing the concept of nation branding, applying nation branding models in different fields like public diplomacy, political marketing, crisis management, cultural products, destination marketing and IMC campaigns. 
Most reviewed studies focused on the effect of nation branding campaigns in destination marketing or place branding field (Shashwat Guptaa , Mohammad M. Foroudib, Juha Väätänenc, Suraksha Guptad, Len Tiu Wright,2020 ), (Staci M. Zavattaroa, Daniel L. Fay,2019).

in other words, how the nation branding can attract tourists and achieve tourists loyalty. ( Keni Keni, Ferry Oktora and Nicholas Wilson, 2019), (Eli Avraham,2020) and also defining the role of nation branding in place marketing for specific areas that suffered from conflicts and wars, as in Timor- Leste ( Sara Currie 2020).

Some studies from the previous theme took specific countries as a case study to determine the role of nation branding and its effectiveness on tourism promotion like India, Romania, Egypt, Tobago ( Finola Kerrigan, Jyotsna Shivanandan, and Anne-Marie Hede,2012 ), (Vinita Manoo,2018), ( Anca-Georgiana ANDREI,2017),(Amani Albert,2017 in Arabic ), ( Marius Bulearca, Suzana Bulearca,2011).

Also, other studies focused on how to measure the success of the place marketing efforts in promoting nation branding in the USA (Staci M. Zavattaroa, Daniel L. Fay,2019)and on the opposite side how nation branding highlights tourism (Anca-Georgiana Andrei,2016 )

Other groups of studies dealt with the nation branding concept from the perspective of hosting mega-events, especially in the sports field and the usage of these events whether in hosting or organizing in implementing nation branding strategies and promoting countries images. ( B. Knott a,n, A. Fyall b, I. Jones,2015),( Xiufang (Leah) Li and Juan Fen 2021), (DANIEL BUARQUE, 2015)

According to the sample, a few studies conceptualize nation branding and present theoretical models of its elements. ( Sajid Karim Mohammad Jasim Uddin,2021) ,( Asri Rashid,2013) 
Few studies present a new perspective of nation branding, which is the role of women empowerment in promoting the positive image of countries. It was found in two studies, one from the United Arab of emirates in shedding light on Mariam El Mansori, the first female air striker (ILHEM ALLAGUI, ABEER AL-NAJJAR 2018 ) and the other from the USA in media coverage of Melania Trump, the former first lady of America ( Maruša Pušnik and Dejan Jontes, 2021 ).

Recent studies tried to focus on nation branding in promoting products or how the product country of origin brand can affect its consumption in local and international markets ( Sutisna Muhari, Furtasan Ali Yusuf, 2020 ),( Kerry Kilduff Julia M. Núñez Tabales , 2016 ), such as promoting Korean products (Arthur Nguyena, Nil Özçaglar-Toulouseb 2021), japan products (Kenichi Ishii. Satoshi Watanabe, 2015), Chinese products (Haritz Gorostidi-Martinez, Weimin Xu and Xiaokang Zha, 2016) and recently how states by nation branding can shape markets (Arthur Nguyena, Nil ÖzçaglarToulouse,2021).

According to the current study, the main issue is how nation branding studies dealt with media and marketing communications in activating and creating nation branding concepts. It was found that many studies directly mentioned and tackled the role of public relations theories and techniques in implementing nation branding strategies( Ruoshi Li,2016), (Kara J. Whytas, 2016 )

as some studies focused on the application of public relations theories and the four main models in nation branding initiatives, others concentrated on crisis and reputation management through nation branding for some countries (Rasmus Kjærgaard Rasmussena, Henrik Merkelsen,2012 ), (Nadia Kaneva \& Delia Popescu,2013)

and the rest of the studies tailored the public relations outcome of nation branding concept in the form of countries images like china, Romania, Greece and Sweden. (James Pamment and Cecilia Cassinger 2018) ( 
Nadia Kaneva, Delia Popescu LeMoyne,2011 ),( Lan He Rongdang Wang Yunnan, China Mingshan Jian, 2020 ), (Periklis Tsikizas, 2013).

Not only the focus of some studies was on public relations but also on the entire integrated marketing communication activities, whether through analyzing advertising campaigns like " incredible India campaign “ (Tamer Abdellatif, Dina Abboud, Sara Mohammed Mamdouh Abd El Azim,2019) and Romania " land of choice " (Marius Bulearca, Suzana Bulearca,2011) or analyzing an integrated nation branding campaign beginning from the logo, slogan of the campaign reaching the usage of different media and programs that serve the same purpose. ( Keith Dinnie,Kai-Uwe Seidenfuss and Ghazali Musa,2010)

Very few studies presented the theme of correlating between nation branding and enhancing the economy and business sustainability. One of them applied to Arab countries like Qatar and the United Arab Emirates and used different strategies to brand themselves as a strong economy. (Cornelia ZEINEDDINE,2017) ,( Meri Frig and Ville-Pekka Sorsa , 2018)

Finally, some studies theorized the role of media in nation branding in two main categories. These studies found that media organizations with policies, values, and people are not neutral channels in transmitting nation branding initiatives. Still, they add in the tone of these campaigns and their track (Göran Bolin, Sweden Galina Miazhevich, 2018), (Galina Miazhevich 2018), GÖRAN BOLIN, PER STÅHLBERG, 2015)

Also, media platforms by their characteristics and attributes can fit in some nation branding campaigns more than others, especially after the appearance of social media. (Dina oraby, Eman Soliman, 2018 in Arabic) (Christian Christensen,2013 ), (Diana Ingenhoff, Giada Calamai, and Efe Sevin,2021), (Lan He Rongdang Wang Yunnan, China Mingshan Jian, 2020), ( Eli Avraham,2020 ), It's worth mentioning that the first study that investigated the role of new media 
in nation branding was in 2011 in examining the second life and virtual environment in nation branding initiatives like a study that applied this concept on Sweden through the Swedish virtual embassy www.secondhouseofsweden.com, (Stina Bengtsson,2011).

\section{Fourth: The theories and models used and resulted from the reviewed studies :}

all the reviewed studies depended on the Anholt model of nation branding hexagon that identifies six main elements in any nation branding initiative, including export, investment and immigration, people, culture and heritage, Governance and tourism. ( Sajid Karim Mohammad Jasim Uddin,2021)

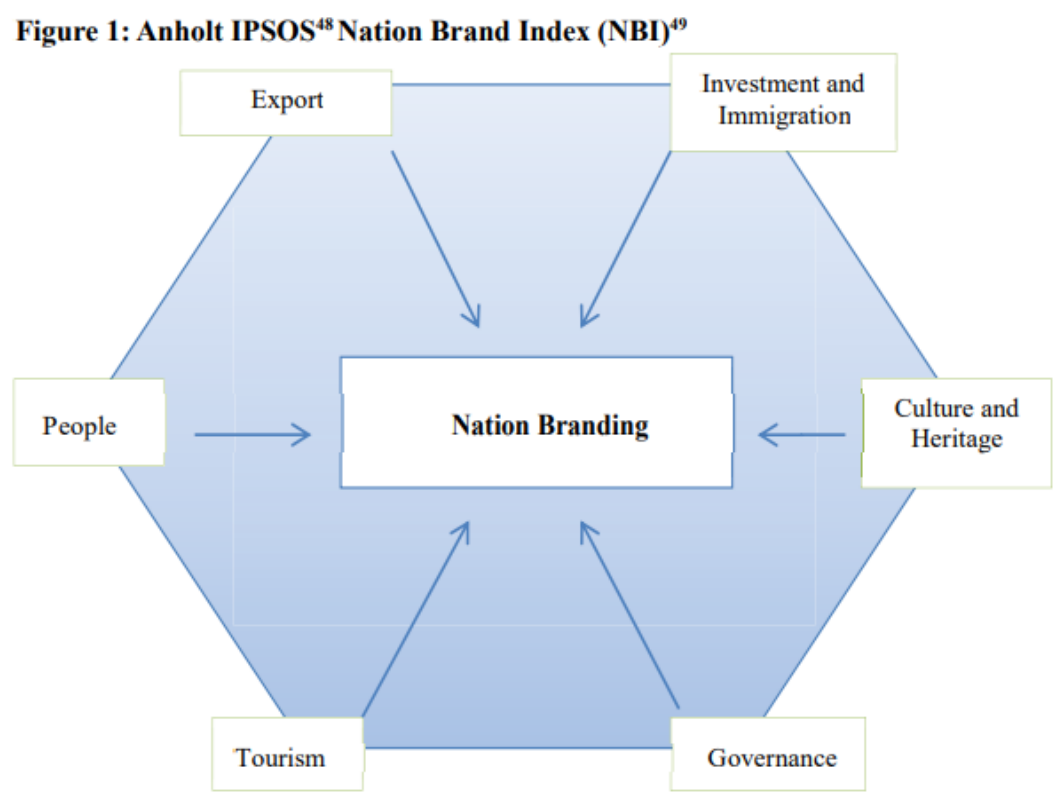

And applied these elements to a specific case study in the form of country nation branding campaign or analyzing governmental 
documents, media coverage, marketing activities that reflect the previously mentioned elements.

But few studies tried to use other theoretical models as a framework in applying their procedures and resulted in proposed models that can be used in future studies.

As per (Shashwat Guptaa, Mohammad M. Foroudib, Juha Väätänenc, Suraksha Guptad, Len Tiu Wright,2020 ), they dealt with the importance of nation branding in the destination marketing field and its effectiveness in attracting tourists and enhancing tourism.

Also, they focused on cinema's role in reflecting images about countries and places. The coming figure shows that it creates the nation branding of the represented country and directly affects travellers' intentions to visit this country.

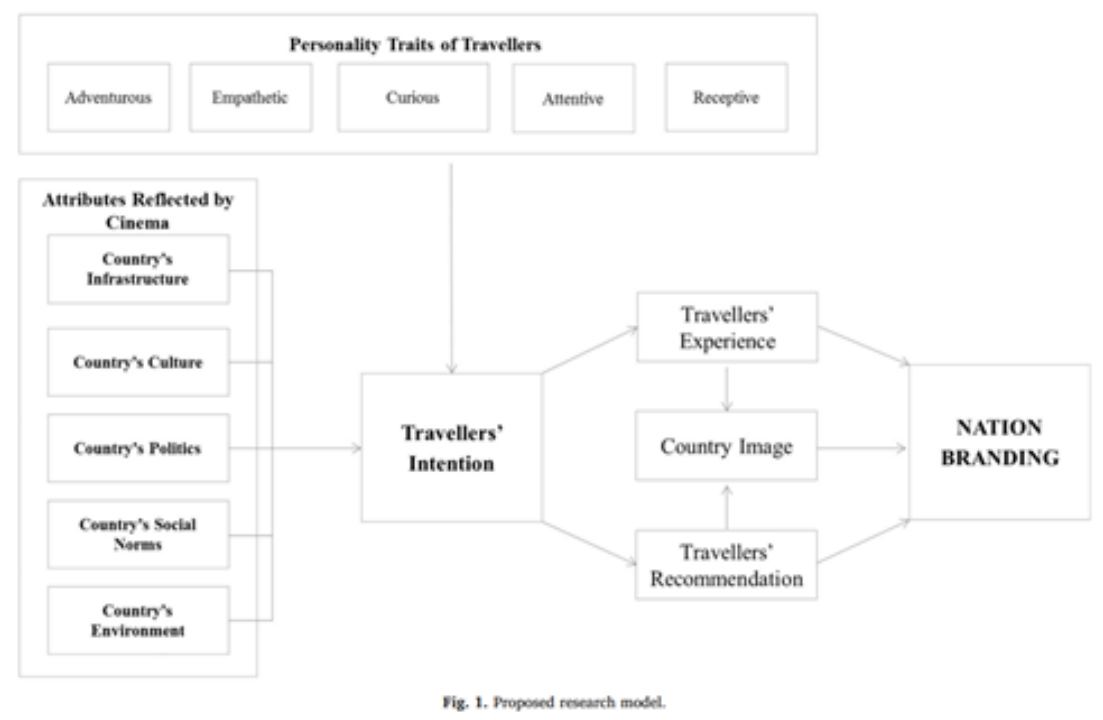

Another study( Asri Rashid,2013)specified conceptualizing the nation branding concept and differentiating the central idea with others like the nation brand image, the national identity, nation image, and national

The Scientific Journal of Public Relations and Advertising Research - Issue Twenty-Second - July / December 2021 
reputation and determined the role of each concept and how it will be achieved.

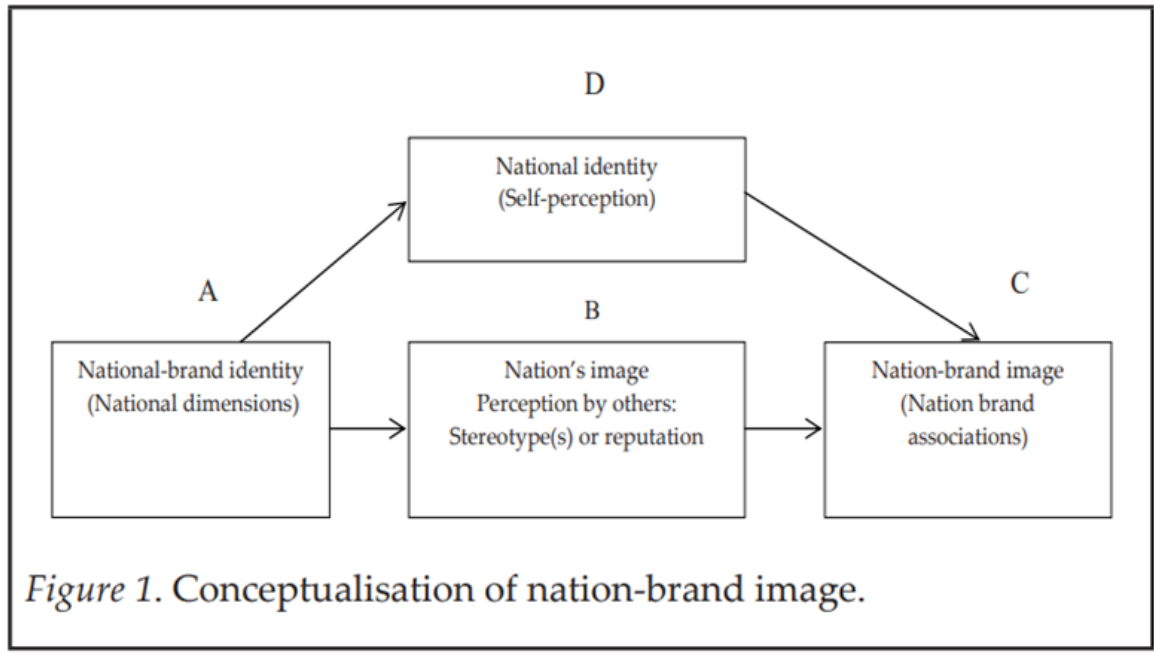

Finally, a recent study (Dalal Iriqat,2019) dealt with applying nation branding on Palestinian policies and found a difference between public diplomacy and nation branding.

And on-ground Palestine needs an accurate, professional nation branding initiative to enhance its situation and promote its right in the international world.

It submitted a detailed comparison as a theoretical framework to distinguish between nation branding and public diplomacy by explaining each concept's operational measurements and elements, like goals, target audiences, sponsors, context, actors, strategies, tactics, media, budget and time. 


\begin{tabular}{|c|c|c|}
\hline & Public diplomacy & Nation braading \\
\hline Goal & Promotiag political interest & Promoting (mostly) economic interest \\
\hline \multirow{3}{*}{ Context } & $\begin{array}{l}\text { Politicised, focus, and priorities may change with } \\
\text { change of govemment }\end{array}$ & $\begin{array}{l}\text { De-politicised, general agreement among actors and } \\
\text { political purties (but in some cases it is politicised) }\end{array}$ \\
\hline & Identity driven & Image driven \\
\hline & Driven by international relations and culture & Driven by masketing and consumerism \\
\hline \multirow{3}{*}{ Targeted at } & Publicsistakeholders who are active & Mass/consumers wbo are passive \\
\hline & Citizens & Consumers (of images, products, and places) \\
\hline & Targeted at key geopolitical countries & Applicable to any countrics, more universal \\
\hline Direction & Forcign publies & $\begin{array}{l}\text { Both foreign and domestic audiences. Without the } \\
\text { consent of dornestic audiences it is doomed to fail }\end{array}$ \\
\hline $\begin{array}{l}\text { Role of } \\
\text { governenent }\end{array}$ & $\begin{array}{l}\text { Initiator as well as sender of messages, government has } \\
\text { more control over message }\end{array}$ & $\begin{array}{l}\text { Government could be the initiator but rarely the sender } \\
\text { (danger of peopaganda) kss or no government coetrol }\end{array}$ \\
\hline Actors & $\begin{array}{l}\text { State and non-state actors government, governmental } \\
\text { organizations, embassies, Ministry of Culture; Ministry } \\
\text { of Foreign Aftairs, Cultural Institutions, NGOs, } \\
\text { diasporas }\end{array}$ & $\begin{array}{l}\text { National tourist boards, travel agencies; investment } \\
\text { promotioe and export agencies; trade boards, chambers } \\
\text { of commerce, multinational organisations, which are all } \\
\text { multipliers }\end{array}$ \\
\hline \multirow{5}{*}{ Strategies } & Relationship building and maintaining & \multirow{2}{*}{ Image management } \\
\hline & Trust building & \\
\hline & Fmphasis on substance and content & Emphasis on visual and symbolic elements \\
\hline & $\begin{array}{l}\text { Decentralised appeoach, in different target countries } \\
\text { different strategies and activities tailoered towards local } \\
\text { audiences }\end{array}$ & $\begin{array}{l}\text { Centralised appeoach, driven by the brand essence } \\
\text { (one-size-fits all) tailored towards a globul and } \\
\text { bomogenous aodicnce }\end{array}$ \\
\hline & $\begin{array}{l}\text { Focus on both positive and negative elements that can } \\
\text { connect people and cultures }\end{array}$ & $\begin{array}{l}\text { Focus exclusively on positive and "marketable" } \\
\text { elements of a country's culture and prople }\end{array}$ \\
\hline Tactics & $\begin{array}{l}\text { Fxhibitions, international film festivals, exchange } \\
\text { programmes, language learniag promotion, networking } \\
\text { anniversaries, PMs, foreign affairs ministers' and ocher } \\
\text { politicians' articles in forciga daily newspapers, genuine } \\
\text { events }\end{array}$ & $\begin{array}{l}\text { Logo and slogan; country advertisements in leading } \\
\text { international TV channels, sponsored pages in leading } \\
\text { intermational magarines; e-marketing, web portals; and } \\
\text { press tours, brochures, pseudo-events }\end{array}$ \\
\hline Media & $\begin{array}{l}\text { Mass modia are less significant, their main role is in } \\
\text { presenting and interpeeting information. Social media } \\
\text { are gettiag more important }\end{array}$ & $\begin{array}{l}\text { Relies beavily on mass media as the main channel. } \\
\text { Media are passive, usually carrying paid advertisements }\end{array}$ \\
\hline Budget & Sponsored by government & Public and peivate partnenship \\
\hline Time frame & Oa-going, continuous & Ad hoc, campaign-driven \\
\hline Evaluation & Shortr, middle- and long- term & Mostly long-term \\
\hline
\end{tabular}

Fifth: methodological frameworks used in the reviewed studies :

The reviewed studies used a variety of methodological frameworks and tools, from the quantitative and qualitative ones. Still, most studies depended on the content analysis method in analyzing advertisements, 
campaigns, media coverage, social media posts and comments and governmental documents.

As for analyzing advertisements ( Eli Avraham,2020 ) examined 70 advertisings on tv. Printed media and youtube channels to evaluate them and their effectiveness in place branding for several countries.

Other studies analyzed complete campaigns to determine the nation branding strategies and its level of success in Germany, Brazil, India, Russia, USA, Romania, Egypt, China ( Anca-Georgiana Andrei,2016),( Finola Kerrigan, Jyotsna Shivanandan, and Anne-Marie Hede,2012 ), (Galina Miazhevich, 2018), (Xiufang (Leah) Li and Juan Fen 2021), (Nadia Kaneva, Delia Popescu, 2011 ),( James Pamment and Cecilia Cassinger 2018),( Diana Ingenhoff, Giada Calamai, and Efe Sevin,2021), ( Amany Albert,2017 in Arabic )

Also, some studies used the content analysis method to analyze media coverage of special events and the news presented in media about specific countries and analyze social media comments, tweets, and governmental documents about rates of tourism and investments as indicators to nation branding campaigns.( Staci M. Zavattaroa, Daniel L. Fay ,2019 ) , ( Arthur Nguyena, Nil Özçaglar-Toulouseb 2021),( Diana Ingenhoff, Giada Calamai, and Efe Sevin,2021),( AncaGeorgiana ANDREI,2017), ( Dina oraby, Eman Soliman,2018 in Arabic ),( Sajid Karim Mohammad Jasim Uddin,2021),( Maruša Pušnik and Dejan Jontes, 2021 )

Questionnaires also was a primary used tool in data collection for the reviewed studies. ( Shashwat Guptaa , Mohammad M. Foroudib, Juha Väätänenc, Suraksha Guptad , Len Tiu Wright,2020 ) (Keni Keni, Ferry Oktora and Nicholas Wilson, 2019), (Lan He Rongdang Wang Yunnan, China Mingshan Jian, 2020), ( Kenichi Ishii, Satoshi Watanabe, 2015).

Other studies combine qualitative methods and quantitative ones in depending on case study as a methodology tool whether in taking 
specific countries and its campaigns as a case study like Romania, Denmark, Greece, Dubai, Qatar, USA, Korea (Rasmus Kjærgaard Rasmussena, Henrik Merkelsen,2012 ), ( Xiufang (Leah) Li and Juan Fen 2021 ),( Nadia Kaneva\& Delia Popescu,2013), ( Periklis Tsikizas, 2013),( Jiyoon Karen Han, Young-A Song, Soyoung Lee, Sujin Kim, and Arnold Dongwoo Chung,2016 ),( Cornelia ZEINEDDINE,2017).

On the other side, some studies depended on qualitative tools only like in-depth interviews with stakeholders of nation branding, media, and marketing experts. (B. Knott a,n, A. Fyall b, I. Jones,2015) ( Sara Currie, 2020),( Vinita Manoo,2018 ) and other studies relied on literature and systematic review for the previous studies in the same field. ( Somogy Varga,2013 ), ( Andy W. Hao, Justin Paul, Sangeeta Trott, Chiquan Guo and Heng-Hui,2019 ), (GÖRAN BOLIN, PER STÅHLBERG,2015),( Ruoshi Li,2016),( Kerry Kilduff, Julia M. Núñez Tabales, 2016).

\section{Sixth: Role of Media and Integrated marketing communications as presented in the reviewed studies}

1- Theorizing the role of media in nation branding studies: the current study tried to explain deeply how the reviewed studies dealt with theorizing, conceptualizing and putting measures for the position of media in nation branding campaigns.

As some studies ( GÖRAN BOLIN, PER STÅHLBERG,2015 ) (Göran Bolin Södertörn, Galina Miazhevich,2018) focused on the role of traditional media from two perspectives, the technological aspects of the media in transmitting the nation images and what is fitting more the visual media or the printed ones.

The other perspective tackled media channels from organizational aspects and institutional policies by raising how media institutions can organize the transmitting of the nation branding strategies, 
considering the extent that the global media policy can permit specific images and values of certain countries.

These studies described Media as the soft power agents; However, the power of Media is neglected in studies; some studies' results explained the importance of media in constructing images, especially if these media platforms are well known and trusted globally like the BBC, CNN, NEWSWEEK.

Another study (Galina Miazhevich, 2018) focused on analyzing specific international channels like Russia TV to know how the news, programs and other media content shaped Russia's brand.

As it called this case " the nation branding with global reach ", this study resulted in the weakness of the country's media channel in promoting its image as it sometimes appears to be contradicting.

Another group of studies focused on the role of social media in promoting nation branding campaigns and strategies as the first study ( Stina Bengtsson,2011) was in 2011 tackled the virtual community of media channels and how Sweden created a complete embassy via the second life and through a website.

It introduces the inference of the internet in the nation branding field by engaging with audiences depending on their interactivity and publishing the international media coverage of Sweden through this website to reflect its international image worldwide.

The other studies shed light on social media role in nation branding through the analysis of social media users (Christian Christensen,2013 ),( Lan He Rongdang Wang, China Mingshan Jian, 2020 ), (Diana Ingenhoff, Giada Calamai, and Efe Sevin,2021) via Twitter, Instagram, Facebook. 
Also, these studies analyzed the local and international audience's perception towards China, Austria, Switzerland, Netherlands by analyzing their comments and hashtags.

These studies called nation branding via social media " public diplomacy 2.0 " by defining the new vital influencers who are the individual accounts with popularity. A massive number of followers play a crucial role in publishing posts and tweets promoting their countries.

Some studies analyzed the official accounts of countries' formal events and campaigns ( Amany Albert,2017), ( Dina oraby , Eman Soliman,2018 ) to determine how these accounts promote the country brand and how the users interact with them.

2- Applying public relations models and marketing strategies in nation branding studies :

a- The reviewed studies that tackled public relations concepts introduced mega-events as a significant public relations tool( B. Knott a,n, A. Fyall b, I. Jones,2015),( Xiufang (Leah) Li and Juan Fen 2021), (DANIEL BUARQUE, 2015) that achieve the emotional heat primarily which are related to sports like branding Africa through world cup events 2006 and other mega sports event.

Other studies used the public relations perspective from the crisis management aspects as public relations techniques are mainly dealing with solving problems and facing a crisis, so some studies focused on the nation branding initiatives that confronted the political and international crisis and considered them as a public relations practices through nation branding campaigns.

This current study found two previous studies concerned with crisis management( Rasmus Kjærgaard Rasmussena, Henrik Merkelsen,2012 ) applied on Danish cartoons crisis in Denmark and 
how public relations create nation branding initiative to face the international threat of terrorism and manage Denmark's reputation.

Another study ( Kara J. Whytas, 2016 ) was concerned with the impact of the commercial crisis of Volkswagen on the image of Germany and how by applying public relations techniques through nation branding campaigns to preserve the positive image of Germany.

Another study dealt with special events from how they correlate to the public relations model( Ruoshi Li,2016 ), as the previous studies mentioned that these events are public relations tools. Still, this study added a detailed explanation of the grunning's communication models, image management theories and reputation management theories applied to theBeijing 2008 opening ceremony and how this event fostered open two-way communication and mutually beneficial relationships.

Based on the previously mentioned study, another study added the audience's participation in nation branding initiative as a development of public relations concept( James Pamment and Cecilia Cassinger 2018 )

as the Swedish number campaign and how the Swedish government created an application through which people from all over the world can call a specific Swedish number and talk to Swedish people to know more about their country.

While the rest of the reviewed studies just mentioned the public relations process from the perspective of image construction applied on various nation branding campaigns for Romania, Bulgaria and Greece, as previously discussed.

b- There were a variety of the reviewed studies that focused on applying the integrated marketing communication approaches,

The Scientific Journal of Public Relations and Advertising Research - Issue Twenty-Second - July / December 2021 
as all the reviewed studies mentioned that nation branding is a marketing campaign that is implemented in different fields like destination marketing, political marketing and commercial marketing in promoting products depending on the image of their country of origin.

But this current study tried to review the studies that applied the integrated marketing communications techniques practically and found three central studies took some case studies and analyzed their marketing communications techniques.

A recent study (Tamer Abdellatif, Dina Abboud. Sara Mohammed Mamdouh Abd El Azim,2019 ) analyzed the " incredible India " campaign to determine the chosen logotype, and the reason behind this design also analyzed the chosen colours of the posters and the various advertisements that reflected the marketing objective of this campaign.

In addition to this, it considered word of mouth in evaluating the effectiveness of marketing communication tools in this campaign.

The second study (Keith Dinnie, Kai-Uwe Seidenfuss University and Ghazali Musa,2010) analyzed the role of the marketing agency and their way in implementing different IMC campaigns as the case of "ASEAN" south-east Asian nations organization, in which this study focused on the role of the marketer or the actor behind the nation branding campaigns.

The third study (Marius Bulearca, Suzana Bulearca,2011) analyzed Romania's nation branding campaign from a complete IMC approach beginning from the traditional advertisements used. In this case, the digital marketing activities were applied, besides the sales promotion strategies and CSR activities executed in this campaign. 
It analyzed the repositioning strategies, the construction of the targeted niche market, the search engine optimization and Google ad words to promote Romania, the $\mathrm{C} 2 \mathrm{C}$ interactions and audiences contests and finally, the published press releases and media kits about this campaign.

\section{Seventh: the main results of the reviewed studies :}

Most of the reviewed studies presented a literature review( Asri Rashid,2013), ( Somogy Varga,2013 ), ( Andy W. Hao, Justin Paul, Sangeeta Trott, Chiquan Guo and Heng-Hui,2019), (GÖRAN BOLIN, PER STÅHLBERG,2015), ( Ruoshi Li,2016), ( Kerry Kilduff, Julia M. Núñez Tabales, 2016) to conceptualize nation branding and differentiate it from the country image, national identity and other related concepts.

As the difference between national identity and nation, branding is selfperception to the country, which results in the identity. This identity shapes the overall branding. In contrast, the nation image is the perception taken by others and collected to form the entire nation reputation or even stereotypes that sometimes nation branding initiatives try to repair.

Another group of studies concentrated on investigating the role of media in creating and organizing nation branding campaigns; their main results were the continuous neglect of defining the role of Media as an institution in promoting countries.

Most of the studies found that media can be used for its technical aspects and how TV and video clips can increase the effectiveness of nation branding activities more than flight magazines. (Göran Bolin Södertörn ,Galina Miazhevich ,2018)

But the recent studies (Galina Miazhevich 2018 ) (Diana Ingenhoff, Giada Calamai, and Efe Sevin,2021), (Lan He Rongdang Wang 
Yunnan, China Mingshan Jian, 2020), ( Eli Avraham,2020 ) found that media play the role of a catalyst or transmitting agent $n$ which its policies and procedures can contribute in the track and direction of the nation branding campaign; also the image and credibility of the channel itself could affect the whole nation image as depending on international channels like $\mathrm{BBC}$ and $\mathrm{CNN}$ is more effective in promoting countries positively as the case of Ukraine.

Social Media is the coming platform for nation branding initiatives, whether for official governmental institutions or for on influencers and citizens as many studies (Christian Christensen,2013 ),( Lan $\mathrm{He}$ Rongdang Wang, China Mingshan Jian, 2020 ), (Diana Ingenhoff, Giada Calamai, and Efe Sevin,2021),( Amany Albert, 2017 in Arabic ), ( Dina oraby, Eman Soliman,2018 in Arabic ) focused on how governments promote their touristic projects or nation branding campaigns via social media platforms like Twitter, Instagram, Facebook.

And they found that these social media campaigns attracted citizens and interacted with them more than traditional media.

As social media users can engage with the content of social media campaigns by comments and shares, citizens participated in nation branding activities through social media like uploading countries photos in Romania case study and Egypt in "this is Egypt" campaign.

And they also found that the word on social media published through influencers can go viral easier than through the traditional media and gain feedback faster.

Public relations theories and models are highly applied in the recent studies( Rasmus Kjærgaard Rasmussena, Henrik Merkelsen,2012 ),( Kara J. Whytas, 2016 ) as all studies explained the nation branding from the public relations perspective, shedding light on the political public relations and public relations of the state. 
Public relations can be applied from putting the theoretical framework of the nation branding initiative to opening communicative discussions with different stakeholders.

Public relation theories of reputation and crisis management are applied primarily to studies investigating the role of nation branding in solving political and international crises of countries.

But studies still use public relations as a theoretical framework without applying practically its techniques.

The image of the product country of origin affects the purchase intentions and behaviours of these products, as many studies ( Sutisna Muhari, Furtasan Ali Yusuf, 2020 ),( Kerry Kilduff Julia M. Núñez Tabales, 2016 )defined the role of nation branding campaigns in promoting cultural, commercial products and found that the word " Made in " is essential in deciding to buy of the products.

Other studies (Cornelia ZEINEDDINE,2017) ( Meri Frig and VillePekka Sorsa, 2018)found a relationship between economic stability, business sustainability in the global market and nation branding as some countries can open their market for the foreign product depending on their international image.

And this perspective applied mainly to Asian and Arab countries as Qatar and Dubai are promoting their image from the perspective of their economic stability and how they contain huge industries in all fields, reaching the extent of promoting their cultural products as a brand.

The main result of this current review is that studies of nation branding developed in the recent decade used to deal with various fields; most studies began to apply nation branding concepts on different case studies. 
But still, the media studies are analyzing the nation branding campaigns without putting a methodological framework for the ideal media performance of media in this field.

Also, most studies associate nation branding with destination marketing, and the dominant use of this field is in tourism and place branding. Still, it was found that nation branding is an accumulative process that can be effective after a long time, and it is an integrated process that cannot be implemented through one aspect and neglect the others.

\section{Conclusion and future vision :}

This current study focused on knowing how the nation branding studies developed especially from the media and marketing perspectives, as all the previous studies and reviews concentrated on presenting the different definitions of the concept itself. However, this study found that the nation branding concept became well known, but applying the concept still needs more elaboration.

Most of the reviewed studies applied to western and Asian countries except three studies applied to Arabic countries and only two studies were written in the Arabic language.

It indicates that the development of nation branding studies is increasing internationally and still needs more Arabic studies to put the accumulative framework of this concept in the Arabic environments.

Most of the studies are theoretical, and literature review and the little number of the applied studies need comprehensive operational definitions and methodological approaches to activate and create models to measure nation branding techniques and strategies accurately.

The reviewed studies show that social media and sports events are crucial elements in promoting nation branding. They are a great

The Scientific Journal of Public Relations and Advertising Research - Issue Twenty-Second - July / December 2021 
opportunity to elaborate the concept and develop new marketing approaches to promote nation branding initiatives.

The promotion of celebrities and persons as part of the nation branding hexagon began to appear in nation branding studies. Most studies focused on tourism marketing campaigns or analyzing media coverage. Still, only two studies investigated the people element to know how it will affect the overall nation branding.

Concerning the future vision of nation branding studies, this study suggests focusing more on the other elements of the nation branding hexagon as the Arabic studies mainly focused on tourism.

Also, the Arabic literature of nation branding is very limited whether finding studies from Arabic researchers, applied on Arabic countries or written in the Arabic language. The future needs more practical studies of nation branding in the different Arabic countries.

Future marketing studies may apply marketing techniques to specific nation branding campaigns and cases to determine their effectiveness and efficiency.

Future studies need to develop an integrated model of defining, measuring and analyzing the nation branding process collecting all its included elements and considering the media, public relations, and marketing effects. 


\section{References:}

-Amany Albert. (2017). Marketing the state as a brand a semiological study of the "This is Egypt" campaign via Instagram. Scientific Journal of Public Relations and Advertising Research. Volume 2017. Article 3. Issue 12. 149204https://sjocs.journals.ekb.eg/article 88341.html (research in Arabic)

-Anca-Georgiana Andrei.(2016). IMPACT OF NATION BRANDING CAMPAIGNS ON COUNTRY IMAGE: GERMANY VS. BRAZIL. Cactus Tourism Journal Vol. 14, Issue 2, Pages 25-32

-Andrei, A.G. (2017), "The impact of nation branding campaigns on country image. Case study: Romania", Management \& Marketing. Challenges for the Knowledge Society, Vol. 12, No. 2, pp. 222-236. DOI: 10.1515/mmcks-2017-0014.

-Andy W. Hao , Justin Pau, Sangeeta Trott ,Chiquan Guo and Heng-Hui Wu.(2019). International Marketing Review Vol. 38 No. 1, 2021 pp. 46-69. at: https://www.emerald.com/insight/0265-1335.htm

-Arthur Nguyena,Nil Özçaglar-Toulouse .(2021) . Nation branding as a marketshaping strategy: A study on South Korean products in Vietnam. Journal of Business
Research
122
(2021)
$131-144$

https://www.sciencedirect.com/science/article/abs/pii/S0148296320305397

-B. Knott, A. Fyall, I. Jones c . (2015). The nation branding opportunities provided by a sport mega-event: South Africa and the 2010 FIFA World Cup. Journal of Destination Marketing \& Management, 4,46-56. http://dx.doi.org/10.1016/j.jdmm.2014.09.001
-BINTANG HANDAYANI, BASRI RASHID.(2013) . CONCEPTUALIZATION OF NATION BRAND IMAGE. IJMS 20 (1), 165-183. at: https://www.researchgate.net/publication/269739450

-Bolin, Göran and Miazhevich, Galina 2018. The soft power of commercialized nationalist symbols: Using media analysis to understand nation branding campaigns. European Journal of Cultural Studies 21 (5), pp. 527-542. 10.1177/1367549417751153 file Publishers page: http://dx.doi.org/10.1177/1367549417751153

-Branka Novčić Korać , Tina Šegota ( 2017) . Branding of a (Desti) nation with a Deteriorated Image: The Case of Serbia. Sociologija i prostor, 55 ,207 (1): 77-99

-Christian Christensen (2013) @Sweden: Curating a Nation on Twitter, Popular Communication, 11:1, 30-46, DOI: 10.1080/15405702.2013.751855 To link to this article: http://dx.doi.org/10.1080/15405702.2013.751855 
-Cornelia ZEINEDDINE .( 2017) . Employing nation branding in the Middle East United Arab Emirates (UAE) and Qatar", Management \& Marketing. Challenges for the Knowledge Society, Vol. 12, No. 2, pp. 208-221. DOI: 10.1515/mmcks-20170013 .

-Dalal Iriqat. (2019). Palestinian Nation Branding via Public Diplomacy. International Relations and Diplomacy, May 2019, Vol. 7, No. 05, 202-216 DOI: 10.17265/23282134/2019.05.002.

https://www.researchgate.net/publication/338855788_Palestinian_Nation_Branding _via_Public Diplomacy

-DANIEL BUARQUE. (2015). One Country, Two Cups - The International Image of Brazil in 1950 and in 2014: A Study of the Reputation and the Identity of Brazil as Projected by the International Media During the Two FIFA World Cups in the Country. International Journal of Communication 9(2015), 1300-1318. Available at http://ijoc.org.

-Diana Ingenhoff , Giada Calamai, and Efe Sevin (2021) . Key Influencers in Public Diplomacy 2.0: A Country-Based Social Network Analysis. Social Media + Society January-March 2021: 1-12 DOI: $\quad 10.1177 / 2056305120981053$ journals.sagepub.com/home/sms

-Dina Orabi, Iman Soliman. (2018). World Youth Forum Creating a nation Brand for Egypt on Twitter. Volume 2018. Article 2. Issue 15 79-53. https://sjocs.journals.ekb.eg/article_104026.html (research in arabic)

DOI 10.1108/IMR-01-2019-0028

-Edith Onowe Odia \& Felix Osaiga Isibor. ( 2014). Strategic Approach to Nation Branding: A Case of the Nigeria Brand. International Journal of Business and Management; Vol. 9, No. 3. (PDF) Strategic Approach to Nation Branding: A Case of the Nigeria Brand (researchgate.net)

-Eli Avraham. ( 2020) . Nation branding and marketing strategies for combatting tourism crises and stereotypes toward destinations. Journal of Business Research,116,711-720. https://doi.org/10.1016/j.jbusres.2018.02.036

-Finola Kerrigan, Jyotsna Shivanandan, and Anne-Marie Hede. (2012). Nation Branding: A Critical Appraisal of Incredible India. Journal of Macromarketing,32(3),319-327DOI: $\quad 10.1177 / 0276146712445788$ http://jmk.sagepub.com

-Galina Miazhevich. ( 2018 ). Nation branding in the post-broadcast era: The case of RT. European Journal of Cultural Studies, Vol. 21(5) 575-593 DOI: $10.1177 / 1367549417751228$ journals.sagepub.com/home/ecs 
-Göran Bolin ,Galina Miazhevich.(2018). The soft power of commercialized nationalist symbols: Using media analysis to understand nation branding campaigns. European Journal of Cultural Studies, Vol. 21(5) 527-542 DOI: $10.1177 / 1367549417751153$ journals.sagepub.com/home/ecs

-GÖRAN BOLIN and PER STÅHLBERG .) (2015) . Mediating the Nation-State: Agency and the Media in Nation-Branding Campaigns. International Journal of Communication 9, 3065-3083. (PDF) Mediating the Nation-State: Agency and the Media in Nation-Branding Campaigns (researchgate.net)

-Haritz Gorostidi-Martinez, Weimin Xu and Xiaokang Zhao.( 2016) . A review of Spanish consumers' product-country image of China. Asia Pacific Journal of Marketing and Logistics Vol. 29 No. 3, 2017 pp. 589-615 DOI 10.1108/APJML-092016-0160. at: www.emeraldinsight.com/1355-5855.htm

-ILHEM ALLAGUI, ABEER AL-NAJJAR.(2018). From Women Empowerment to Nation Branding: A Case Study From the United Arab Emirates. International Journal of Communication,12,68-85. Available at http://ijoc.org

-James Pamment and Cecilia Cassinger. ( 2018). Nation branding and the social imaginary of participation: An exploratory study of the Swedish Number campaign. European Journal of Cultural Studies, Vol. 21(5) 561-574 DOI: $10.1177 / 1367549417751152$ journals.sagepub.com/home/ecs

-Jiyoon Karen Han, Young-A Song, Soyoung Lee, Sujin Kim, and Arnold Dongwoo Chung. (2016). , Let's Get Engaged! Crossing the Threshold of Marketing's Engagement Era, Developments in Marketing Science: Proceedings of the Academy of Marketing Science, DOI 10.1007/978-3-319-11815-4_256

-Jos éI. Rojas-M é ndez ,Nicolas Papadopoulos ,Steven A. Murphy.( 2013) . Measuring and Positioning Nation Brands: A Comparative Brand Personality Approach. Corporate Reputation Review, Vol. 16, No. 1, pp. 48-65. https://www.researchgate.net/publication/263339140_Measuring_and_Positioning Nation_Brands_A Comparative_Brand_Personality_Approach

-Kara J. Whytas. ( 2016 ) . Impact of a Brand Crisis on Nation Branding: An Analysis of Tweets about VW's Emissions Crisis. https://digitalcommons.usf.edu/cgi/viewcontent.cgi?article=7628\&context=etd

-Keith Dinnie .( 2016) . Nation Branding : Concepts, Issues, Practice $.2^{\text {nd }}$ edition .Routledge. 304 pages .

-Keni Keni, Ferry Oktora and Nicholas Wilson. (2018). The Impact of Destination Image and Perceived Quality on Tourist Loyalty in the Indonesian Tourism Industry. DOI: 10.5220/0008488300670075 In Proceedings of the 7th International Conference on Entrepreneurship and Business Management (ICEBM Untar 2018), pages 67-75.

The Scientific Journal of Public Relations and Advertising Research - Issue Twenty-Second - July / December 2021 
-Kenichi Ishii, Satoshi Watanabe. ( 2014) . Nation brand personality and product evaluation among Japanese people: Implications for nation branding. Place Branding and Public Diplomacy Vol. 11, 1, 51-64 www.palgrave-journals.com/pb/

-Kerry Kilduff, Julia M. Núñez Tabales .( 2017). Country Branding and its effect on the consumer in the global market. Cuadernos de Gestión Vol. 17 - No 1, pp. 83-104. (PDF) Country Branding and its impact on the consumer in the worldwide market (researchgate.net)

-Lan He , Rongdang Wang ,Mingshan Jiang . (2020) . Evaluating the effectiveness of China's nation branding with data from social media, Global Media and China, Vol. 5(1) 3-21 DOI: 10.1177/2059436419885539 journals.sagepub.com/home/gch

-Larry V. Hedges , Julian P. T. Higgins, Hannah R. Rothstein, Michael Borenstein .( 2021 ) introduction to meta analysis . wiley . $1^{\text {st }}$ edition .

-Marius Bulearca, Suzana Bulearca.(2011). Romania branding campaign - an IMC perspective. International Journal of Business, Management and Social Sciences Vol. 2, No. 3, pp. 35-58. (PDF) Romania branding campaign-an IMC perspective (researchgate.net)

-Maruša Pušnik and Dejan Jontes .( 2021). The nation as an imagined commodity: Branding 'Melania'. European Journal of Cultural Studies 1-20 DOI: 10.1177/13675494211014910 journals.sagepub.com/home/ecs

-Meri Frig and Ville-Pekka Sorsa.(2018). Nation Branding as Sustainability Governance: A Comparative Case Analysis. Business \& Society 2020, Vol. 59(6) 1151-1180.DOI: 10.1177/0007650318758322 journals.sagepub.com/home/bas

-Nadia Kaneva \& Delia Popescu .( 2014 ) . "We are Romanian, not Roma": Nation Branding and Postsocialist Discourses of Alterity. Communication, Culture \& Critique, 7, 506-523.

-Nadia Kaneva , Delia Popescu .( 2011) . National identity lite Nation branding in post-Communist Romania and Bulgaria. INTERNATIONAL journal of CULTURAL studies, Volume 14(2): 191-207 DOI: 10.1177/1367877910382181, ics.sagepub.com

-Periklis Tsikizas. ( 2013). The Use of Social Media as Communication Channels in Nation Branding \& New Public Diplomacy Acts: A study on the "Up Greek Tourism" project in contemporary Greece https://www.divaportal.org/smash/get/diva2:663227/FULLTEXT01.pdf

-Rasmus Kjærgaard Rasmussena, Henrik Merkelsen.(2012) . The new PR of states: How nation branding practices affect the security function of public diplomacy. Public Relations Review, 38,810-818. http://dx.doi.org/10.1016/j.pubrev.2012.06.007 
-Robert Govers. (2011). Brand Dubai and its competitors in the Middle East: An image and reputation analysis. Place Branding and Public Diplomacy, 8, 48 - 57. DOI: 10.1057/pb.2011.30. (PDF) Brand Dubai and its competitors in the Middle East: An image and reputation analysis (researchgate.net)

-Ruoshi Li .( 2016) . Analyzing Nation Branding Through Public Relations Lenses-the Case of the 2008 Olympics Opening Ceremony. Dissertations - ALL. 545. https://surface.syr.edu/etd/545

-Sajid Karim , Mohammad Jasim Uddin(2020). NATION BRANDING OF BANGLADESH: EXPLORING THE POTENTIAL AND THE PROCESS. BIISS JOURNAL, VOL. 42, NO. 3, JULY 2021: 229-256.

-Sara Currie. (2020). Measuring and improving the image of a post-conflict nation: The impact of destination branding. Journal of Destination Marketing \& Management ,18 , $100472,1-10$. https://doi.org/10.1016/j.jdmm.2020.100472

-Schulze, R. (2004). Meta-analysis: A comparison of approaches. Hogrefe \& Huber Publishers.

-Shashwat Guptaa , Mohammad M. Foroudib, Juha Väätänenc, Suraksha Guptad, Len Tiu Wright. (2020). Nations as brands: Cinema's place in the branding role. Journal of Business Research,116,721-733. https://doi.org/10.1016/j.jbusres.2018.02.017

-Somogy Varga. (2013). The politics of Nation Branding: Collective identity and public sphere in the neoliberal state. Philosophy and Social Criticism 39(8) 825-845. DOI: $10.1177 / 0191453713494969$ psc.sagepub.com

-Staci M. Zavattaroa, Daniel L. Fayb .(2019) . Brand USA: A natural quasiexperiment evaluating the success of a national marketing campaign. Tourism Management,70,42-48. https://doi.org/10.1016/j.tourman.2018.07.013

-Stephen M. Croucher, Daniel Cronn-Mills .(2021). Understanding Communication Research Methods

A Theoretical and Practical Approach $.3^{\text {rd }}$ edition , Routledge ,334 Pages .

-Stina Bengtsson ( 2011). Virtual nation branding: the Swedish embassy in Second Life. Journal of Virtual Worlds Research - Virtual Nation Branding, volume 4, no.1, 1-28 https://journals.tdl.org/jvwr/index.php/jvwr/article/view/2111

-Sutisna Muhari, Furtasan Ali Yusuf ( 2020). Brand Image of Domestic Products: Empirical Evidence From Indonesia. PSYCHOLOGY AND EDUCATION,57(9): 2117-2129. (PDF) Brand Image of Domestic Products: Empirical Evidence From Indonesia (researchgate.net)

-Tafadzwa Matiza ,Olabanji. A. Oni . ( 2013). Nation Branding as a Strategic Marketing Approach to Foreign Direct Investment Promotion: The Case of

The Scientific Journal of Public Relations and Advertising Research - Issue Twenty-Second - July / December 2021 
Zimbabwe. Mediterranean Journal of Social Sciences, vol. 4 . no.13, 475-488. https://www.mcser.org/journal/index.php/mjss/article/view/1538

-Tamer Abdellatif, Dina Abboud and Sara Mohammed Mamdouh Abd El Azim .( 2019). The role of advertising design in nation branding (With applying to India branding campaign 2002) https://mjaf.journals.ekb.eg/article_48201_5441b870a328d92c81609149b583e864.p $\underline{\mathrm{df}}$

-Ulla Hakala ,Arja Lemmetyinen and Satu-Pa ivi Kantola.(2013). Country image as a nation-branding tool. Marketing Intelligence \& Planning Vol. 31 No. 5, pp. 538- 556 DOI 10.1108/MIP-04-2013-0060 www.emeraldinsight.com/0263-4503.htm

-Vinita Manoo ( 2018 ). Destination and Nation Branding in Trinidad and Tobago. https://www.academia.edu/38386882/Destination_Branding_and_Nation_Branding in Trinidad and Tobago

-Xiufang (Leah) Li and Juan Feng .( 2021) . Nation branding through the lens of soccer: Using a sports nation branding framework to explore the case of China. European Journal of Cultural Studies 1-21 DOI: 10.1177/13675494211011179 journals.sagepub.com/home/ecs 